\title{
TOWARDS A REVISION OF THE HAKEA EPIGLOTTIS LABILL. (PROTEACEAE) COMPLEX OF TASMANIA
}

\author{
by R.M. Barker \\ (with one text-figure)
}

\begin{abstract}
Hake megadenia, a new species closely related to H. epiglottis, is described from the east coast of Tasmania, Furneau Islands. Distinctions between the species are discussed together with a consideration of the status of $H$. milliganit. Key Words: Hakea, Tasmania.

In BANKS, M.R. et al. (Eds), 1991 (31 :iii): ASPECTS OF TASMANIAN BOTANY - A TRIBUTE TO WINIFRED CURTIS. Roy. Soc. Tasm. Hobart: 79-84. https://doi.org/10.26749/rstpp.124.2.79
\end{abstract}

\section{INTRODUCTION}

In revising Hake for the forthcoming Flor of Australia treatment with Drs W.R. Barker and L. Haegi, the genus was divided into apparently natural groupings. Amongst the groupings allocated to the author was the H.rostrata group characterised by sigmoid fruits and the perianth with appressed-pubescent hairs and a small gland at the front of the torus. This group includes the endemic Tasmanian species $H$. epiglottis; initial study of herbarium material of this species revealed at least two taxa separable on relatively minor characters. Contact with Mr Amold Himson of Sandford, Tasmania, and Dr Winifred Curtis showed that both recognised two taxa within $H$. epiglottis, separating them primarily on flower colour, one having cream-white flowers the other yellow.

A paper on the biology of H. epiglottis (Lee 1987) provided some basic information on the distribution of dioecious and bisexual populations of $H$. epiglottis but did not distinguish between the two taxa recognised here.

Describing a new species, H. megadenia, closely related to $H$. epiglottis, seems to make some progress in unravelling the intricacies of this complex. However, there still remain numerous questions that can only be answered by a closer look at populations in the field. One such problem is the status of $H$. milliganii discussed below.

\section{BREEDING SYSTEM IN THE COMPLEX}

Both species are apparently diclinous, with $H$. megadenia dioecious, i.e. having functionally male and female flowers on separate plants within the same population, while H. epiglottis appears to be trioecious, i.e. producing functionally male, female and bisexual flowers on separate plants (terminology after Richards 1986). Most stands of $H$. epiglottis are apparently composed of functionally male and female plants (Stones \& Curtis 1978, Lee 1987). Annotations on herbarium sheets suggest that male and female plants are in more or less equal numbers when judged by the number of bushes with fruit. Other populations of $H$. epiglottis, in which the bushes apparently all produce bisexual flowers, occur near Beaconsfield, in northern Tasmania, and in the Longley Margate area near Hobart (Lee 1987). Lee_also documented some functionally male plants from Breona being found to have a few fruits on old branches and suggested that these fruits were produced in the first years of flowering. Such an observation may account for a collection from Mt Field (Rodway s.n., December 1910, HO) in which the flowers were found to be bisexual rather than the more usual unisexual from this area.

\section{DISTINCTION BETWEEN $H$. EPIGLOTTIS AND H. MEGADENIA}

The two species, as recognised here, have different but slightly overlapping distributions (fig. 1) and do not overlap in flowering time. Besides the geographic and reproductive isolation of these two taxa, there are also, apparently, differences in gland size, flower colour, habit and, over some of the range, fruit characters. Information on lignotuber differences between the species, often a reliable character elsewhere in the genus - for example between $H$. baxteri and H.brownii in Western Australia (Barker 1990) and within the H. ulicina complex (Haegi \& Barker 1985) - is lacking. 

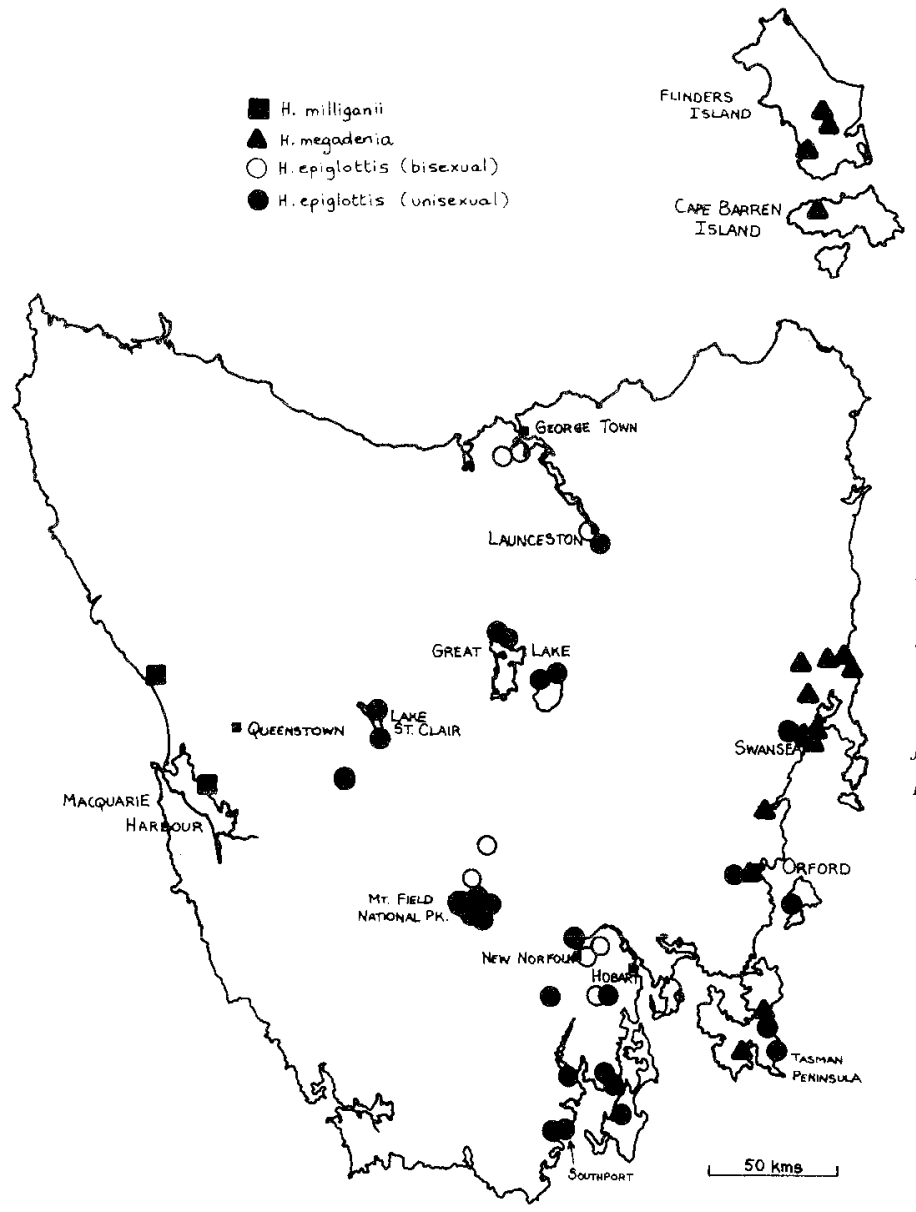

FIG. 1 - Distribution of Hakea epiglottis Labill, including bisexual and unisexual populations and specimens referrable to H.milliganii, and H.megadenia R.M.Barker.Only flowering specimens have been plotted.

\section{Gland Size}

From herbarium sheets the only character able to be used with any consistency to separate the taxa has been the size of the gland at the front of the torus. In male, female and bisexual flowers of $H$. epiglottis the gland is never more than $0.5 \mathrm{~mm}$ high, while in male and female flowers of $H$. megadenia it is always $0.6-0.9 \mathrm{~mm}$. Since this has been the predominant character used to distinguish the taxa, only herbarium sheets with flowering specimens could be allocated to either species with any confidence. Some collections in which no flowers were present were allocated to a species on the basis of the size of the gland on the young fruit. Whether the differing gland sizes and flowering times of the species indicates a difference in pollinators warrants investigation.
A consideration of flower colour based on herbarium sheet data proved impractical. Flowers are invariably referred to as yellow, cream or white despite the fact that both species have white hairs externally. Both Dr Curtis and Mr Himson refer to yellow flowers for $H$. epiglottis and cream-white flowers for $H$. megadenia, presumably on the basis of the internal coloration of the perianth. Comparisons in colour are difficult because the two species flower at different times. There are possibly other colour differences within the flowers of the $H$. epiglottis complex as one cultivated specimen from the Canberra Botanic Gardens (W.R. Barker 5692) is recorded as having a red style instead of the usual yellow one. This colour variant is also depicted in Stones \& Curtis (1978). 


\section{Habit}

$H$. epiglottis is usually a bushy compact shrub to $3 \mathrm{~m}$ tall while $H$. megadenia is an erect shrub or small tree up to $7 \mathrm{~m}$ high. Unfortunately, most of the herbarium specimens seen which could be allocated to either of the species lacked information on habit.

\section{Fruit Characters}

Fruit size can be a guide to the separation of the two species but there is overlap. Fruits smaller than $18 \mathrm{~mm}$ long and not noticeably woody usually belong to H. epiglottis, but longer fruits could belong to either species. Those collections from the southwest and from the west coast of Tasmania which are referrable to $H$. epiglottis frequently have fruits up to $28 \mathrm{~mm}$ long, tending to be woodier than those from alpine areas and the Hobart area. In this respect they are indistinguishable from the fruits of $H$. megadenia. Curtis (1967) used a character involving the outer surface of the fruit in which the folds were described as rounded or sharp, but I have not found this to be workable. This inability to distinguish the species purely on the basis of the fruit has led to difficulties in typification, as the type collection has fruits but no flowers (see typification of H. epiglottis).

\section{Lignotubers}

Observations made by Lee (1987) indicate that some populations of $H$. epiglottis sens. lat. have lignotubers while others do not. Whether the presence or absence of a lignotuber correlates with the taxa delineated here is not known. Lee notes the lack of a lignotuber by the lack of resprouting after disturbance such as earthworks or fire, recorded in populations from Lake Leake Rd, Margate and Freycinet Peninsula, localities at which both of the taxa treated here seem to overlap. In contrast, lignotuberous plants were observed by Lee at Cashs Lookout and Balts Road on the Tasman Peninsula, again localities where $H$. epiglottis and $H$. megadenia overlap. The latter observations are supported by Dr Curtis (in litt. 27.iv.1988), who suggested that a lignotuberous form of $H$. epiglottis occupies the heaths of the Tasman Peninsula. It needs to be established whether the lignotuberous populations of the Tasman Peninsula are conspecific with $H$. megadenia or H. epiglottis.

\section{Geographic Separation}

$H$. megadenia is found on the Furneaux Islands, north of Tasmania, and on the east coast as far south as Tasman Peninsula. H. epiglottis is found throughout the rest of the state, although the true distribution is unclear, as so many herbarium specimens lack flowers. The two species apparently overlap in the Orford area, on Tasman Peninsula and in the Swansea area but possibly occupy different ecological sites. H. rugosa and $H$.rostrata, two species closely related to $H$. epiglottis, have previously been recorded for Tasmania by Curtis (1967), but, as indicated by Lee (1987) do not occur there, the original recordings having been based on misidentified $H$. epiglottis specimens.

\section{Flowering Time}

H. epiglottis flowers in spring to early summer, between September and December while $H$. megadenia flowers in late summer to winter from February to July.

\section{THE STATUS OF HAKEA MILLIGANII}

Hakea milliganii possibly deserves some recognition as an infraspecific taxon within $H$. epiglottis but, at this stage is only known from the type collection from Macquarie Harbour and probably one other from near Remine. The NSW specimen from Remine was collected by W.V.Fitzgerald in September 1893. Another specimen in MEL matches the Fitzgerald collection in the date and characteristics of the material but has been attributed to Weindorfer. However, Weindorfer did not arrive in Australia until 1899 (Sutton 1932), so the specimen in MEL is probably a duplicate of the Fitzgerald one.

H. milliganil is distinguished from $H$. epiglottis and $H$. megadenia by the perianth parts having pale-brown appressed-pubescent hairs on the claw with contrasting rust-coloured hairs on the limb. Pale-brown and rustcoloured hairs do occur on the perianth parts of $H$. epiglottis but they are usually sparse compared with the white or cream-yellow hairs. While no modern collections exhibiting these characteristics have been seen, there is a small bush growing in Wittunga Botanic Gardens, Adelaide (W.R. Barker 5505) and another in Canberra Botanic Gardens (W.R. Barker 5692) in which the flowers do conform with those of $H$. milliganii. Further collections from the west coast of Tasmania may indicate whether a distinctive taxon occurs there. From the specimens seen, flowering occurs in September, the gland is less than $0.5 \mathrm{~mm}$ high and the fruit c. $23 \mathrm{~mm}$ long. Pollen was found in flowers on 
fruit-bearing branches, indicating a possible difference in breeding system from $H$. epiglottis.

\section{SPECIES DESCRIPTIONS}

Hakea epiglottis and H. megadenia are the only Hakea species in Tasmania with sigmoid fruit and so should be easily idenifiable. In the absence of fruits, the only other Hakea species in Tasmania to have pubescent flowers is $H$. teretifolia, which is distinguishable from $H$. epiglottis and $H$. megadenia by its rigid leaves, its perianth with dirty-brown tomentose hairs and the longer (11-17 mm) pistil, and also the larger $(4.5-6.5 \mathrm{~mm}$ long) glabrous involucral bud compared with the 1.5$4 \mathrm{~mm}$ long, pubescent bud in $H$. epiglottis and H. megadenia.

\section{Hakea epiglottis Labill.}

Hakea epiglottis Labill., Novae Hollandiae Plantarum Specimen 1:30, t.40 (1805). Syntypes: J. Labil lardières.n., Capite Van Diemen (FIn.v., GHerb.DC. (fiche AD), G - Herb. Webb, GHerb. Moricand, P - Herb. Webb, P - Herb. Jussieu 4148 (fiche BRI), K p.p., OXF).

H. milliganii Meissner (as H. milligani) in A.DC., Prodr.14:395(1856). Lectotype here designated: J. Milligan 737, 10.x.1846, (NY) In Ins. Diemen, occidentali, circa Macquarie harbour (NY), isolectotype and ?syntype: $\mathrm{K}$; isolectotype, not syntype: HO.

H. rostrata auct. non F.Muell.: Curtis, Students Fl. Tasm. 3 (1967), 609 p.p.

H. rugosa auct. non R.Br.: Curtis, Students Fl. Tasm.3 (1967), 609 p.p.

\section{Description}

Compact shrubs up to $3 \mathrm{~m}$ high, polygamous but most populations apparently dioecious (see above). Branchlets densely appressed-pubescent or densely appressed-sericeous with red or red and white hairs, quickly glabrescent or persistent sometimes until fruiting, glaucous or not, red. Leaves alternate and spirally arranged, obliquely spreading, simple, terete, $15-75(-110) \mathrm{mm}$ long, $1.0-2.0 \mathrm{~mm}$ broad, flexible, not grooved, densely appressed-sericeous with red and white hairs, quickly glabrescent or glabrescent by flowering, not glaucous; mucro usually porrect, rarely uncinate, $0.5-1 \mathrm{~mm}$ long. Inflorescence an axillary umbel; inflorescence-subtending bracts forming a cone-like involucre in bud; involucre $3-4 \mathrm{~mm}$ long, densely tomentose. Flowers up to 8 per axil in male plants, $1-3$ in female plants, $2-6$ when bisexual; rhachis
1-3 mm long, densely villous, hairs white, creamyellow or rust-brown, persistent; pedicel $3.5-5 \mathrm{~mm}$ long, densely tomentose with some hairs appressed or densely appressed-sericeous with some hairs raised, hairs white or pale brown; perianth $2.5-4.5 \mathrm{~mm}$ long, yellow, densely appressed-pubescent or densely appressed-sericeous, hairs white, pale brown or rustbrown; anthers $0.4-0.5 \mathrm{~mm}$ long, lacking pollen in female flowers; gland V-shaped in X-section, 0.2$0.3(-0.5) \mathrm{mm}$ high in male, female and bisexual flowers; pistil obliquely inserted, $5-8 \mathrm{~mm}$ long; style obliquely inserted on ovary, 7-10 times longer than gynophore, recurved and remaining so; pollen presenter oblique or almost lateral, $0.5-0.7 \mathrm{~mm}$ long, cone present or absent. Fruit oblique or lateral on a short stalk, usually 1, sometimes a number crowded together, sigmoid, 14 $18(-28) \mathrm{mm}$ long, $6-13 \mathrm{~mm}$ wide, finely or coarsely rugose, rugose-reticulate or smooth, gradually attenuate, dehiscing fully down one side, almost fully down the other; apiculum recurved, $4 \mathrm{~mm}$ long, bearing obscure homs. Seed obovate, one side almost straight, 9-12 mm long, 4-5 mm broad, narrowly acute proximally, rounded distally; seed-body 4-6 mm long, coarsely rugose, rugose-reticulate or smooth; distal ridge obscure; wing extending narrowly and partly down one side only, black or mid brown.

Shrubby heaths from coastal to alpine areas. Flowering September to December.

\section{Typification}

The major part of Labillardière's herbarium is housed in the Webb herbarium in FI (Stafleu \& Cowan 197688 ). This collection has not yet been seen and so the species has not been lectotypified here. Despite this, six other syntypes have been seen, two of these from the Webb herbarium in $P$ and $G$ and so it is unlikely that the collection in FI will differ.

The type collection by Labillardière only has mature fruits c. $19 \mathrm{~mm}$ long and so it is impossible to state definitely that it belongs with $H$. epiglottis as circumscribed here. It seems likely that it does on the basis of the collecting localities of Labillardière combined with a consideration of flowering time of the two species. Labillardière collected along the southeast coast of Tasmania from Recherche Bay and along the D'Entrecasteaux Channel on two occasions, the first from 21 April-28 May 1792 and the second from 21 January-27 February 1793 (Brosse 1983). Labillardière's own account (1800) also mentions visiting Cape Pillar and Maria Island on the second visit. Most material from these areas falls within H. epiglottis as circumscribed here. The lack of flowers on the specimens combined with the presence of young pubescent branchlets tends to support the identification as $H$. epiglottis. Young branchlets develop in both 
species after flowering. If the Labillardière collection had been $H$. megadenia then some signs of flowers or at least buds could be expected, while if it was $H$. epiglottis then flowers would not be expected but young developing branchlets would.

\section{Note}

Unisexual plants in populations can be detected by examining the flowers. Those plants which have functionally male flowers produce copious pollen on a pollen presenter in which the surface is almost concave. Such plants do not produce fruit. Functionally female plants have flowers in which the anthers are sterile and no pollen is produced. The pollen presenter of the female flower has a prominent conical protuberance at the apex of which is a ring of stout hairs (Lee 1987, figs $2-6)$. These plants produce fruit. Bisexual flowers are produced in some populations.

\section{Specimens Examined (selection only)}

Flowering specimens only; probably referrable to the unisexual form: A.M. Buchanan 4205 (HO), J.H. Hemsley 6315 (HO, NSW), M.E. Phillips s.n. (CBG5238), D.W. Shoobridge s.n. (CBG14267), C. Stuart 1656 (MEL).

Cultivated: N. Ali s.n. (HO56154).

Unisexual form: A.M. Gray 569-573 (HO), A. Moscal 8657 (AD), D.A. \& A.V. Ratkowsky 838 (NSW).

Bisexual form: Anon. [R. Gunn] 1235/1842 (NSW 182388), R. Brown 3383 (BM, E p.p., K p.p.), P. Collier 4108 (AD, HO), S.J. Jarman 8 (AD, BRI, CBG, NT, MEL), L. Rodway s.n. (HO20314), L. Rodway s.n. (HO20303).

H. epiglottis specimens referrable to H. milliganii: W.V. ?Fitzgerald s.n. (MEL 571278), W.V. Fitzgerald s.n. (NSW182384), R.C. Gunn 737 (HO, W). J. Milligan s.n. (BM), J. Milligan 737 (K, NT).

Cultivated: W.R. Barker 5505 \& R.M. Barker (AD). [Further details of specimens listed in this paper, e.g. collecting site and date, are available from the Herbaria noted or from the Royal Society of Tasmania Library (Archives), GPO Box 1166M, Hobart, Tasmania, Australia 7001. Ed.]

\section{Hakea megadenia R.M. Barker, sp. nov.}

Species nova prope $H$. epiglottis sed differt glande triloba maiore, floribus eburneis, florescentia autumnali et in distributione geographica.

\section{Holotype}

J. Armstrong 867 \& J. Powell, 17.v.1976, scenic lookout on road to Swansea (HO). Isotype: NSW.
H. rostrata auct. non F.Muell.: Curtis, Students Fl. Tasm.3 (1967) 609 p.p.

H. rugosa auct. non R.Br.: Curtis, Students Fl. Tasm. 3 (1967) 609, probably p.p.

\section{Description}

Dioecious shrubs or small trees, 3-5(-7) $\mathrm{m}$ tall. Branchlets densely appressed-pubescent, not sericeous, hairs red or red and white, persistent until flowering. Leaves alternate and spirally arranged, obliquely spreading, simple, terete, 35-135 mm long, 1.0-1.8 $\mathrm{mm}$ broad, not grooved, densely appressed-sericeous, hairs red and white, quickly glabrescent or glabrescent by flowering, not glaucous; mucro usually porrect, rarely uncinate, $0.5-1 \mathrm{~mm}$ long. Inflorescence an axillary umbel or umbelliform raceme; inflorescence-subtending bracts forming a cone-like involucre in bud; involucre 1.5-2 mm long, densely tomentose. Flowers $1-8(-14)$ per axil in both female and male plants; rhachis 1-3 $\mathrm{mm}$ long, densely villous, hairs rust-brown, persistent; pedicel 2-5 mm long, densely appressed-sericeous, hairs white; perianth $2.5-4.5 \mathrm{~mm}$ long, cream-white, densely appressed-sericeous, hairs white; anthers 0.4 $0.5 \mathrm{~mm}$ long, lacking pollen in female flowers; gland a trilobed flap, $0.6-0.9 \mathrm{~mm}$ high in male and female flowers; pistil obliquely inserted, 5-8 mm long; style obliquely inserted on ovary, 7-10 times longer than gynophore, recurved and remaining so; pollen presenter oblique or almost lateral, $0.5-0.7 \mathrm{~mm}$ long, cone present or absent. Fruit oblique or lateral on a short stalk, usually 1 , sometimes a number coalesced together, sigmoid, (18-)22-25 mm long, 9--12 mm wide, finely or coarsely rugose or smooth, gradually attenuate, dehiscing fully down one side, almost fully down the other; apiculum recurved, $4 \mathrm{~mm}$ long, bearing obscure horns. Seed obovate, one side almost straight, c. 10.5 $\mathrm{mm}$ long, c. $4.5 \mathrm{~mm}$ broad, narrowly acute proximally, rounded distally; seed-body $4-6 \mathrm{~mm}$ long, coarsely rugose, rugose-reticulate or smooth; distal ridge obscure; wing extending narrowly and partly down one side only, black or mid-brown.

\section{Distribution and Ecology}

Riverside shrubbery or dry open forest, low altitude and coastal on the mainland but at higher altitudes on the islands. On the mainland at least, often associated with Leptospermum grandiflorum Lodd. Flowering February to July.

\section{Note}

Specimens from the Furneaux Islands are consistently more robust than those from the mainland. They have more flowers per axil, somewhat larger perianth and the fruits are always in the larger end of the size range. 


\section{Specimens Examined (selection only)}

A.M. Buchanan 3605 (HO), B.C. Crisp 455 (CBG); A. Himson B per R.M. Barker (AD 98715206); A. Moscal 418 (HO); L. Rodway s.n. (HO 20377); J. Whinray s.n. (NSW 100534); J.S. Whinray 134 (HO 25852), 1927 (CANB); 438 (MEL); J.H. Willis s.n. (MEL 515109).

\section{ACKNOWLEDGEMENTS}

This work was carried out at the State Herbarium of S.A. and partly funded by an Australian Biological Research Study grant. Mr Arnold Himson of Sandford provided helpful comments on distinctions between the two species, as well as specimens from his collections. Dr Winifred Curtis parted freely with her knowledge of the $H$. epiglottis complex and also provided helpful comments. The author is grateful to both these people and to Dr Tony Orchard for arranging contact with them. Peter Weston is thanked for his critical comments and the author's husband, Bill, for providing encouragement, computer literacy and critical comments on the manuscript.

\section{REFERENCES}

BARKER, R.M., 1990: New species, new combinations and olher name changes, in Hakes (Proteaceae). $J$. Adelaide Bot. Gard. 13: 95-110.
Brosse, J., 1983: LES TOURS DU MONDE DES EXPLORATEURS: LES GRANDS VOYAGES MARITIMES, 1764-1863. (English translation: GREAT VOYAGES OF EXPLORATION. Doubleday, Lane Cove, N.S.W.

CURTIS, W.M., 1967: THE STUDENT'S FLORA OF TASMANIA, PART 3. Government Printer, Hobart.

HAEGI, L. \& BARKER, W.R., 1985: Taxonomy of the South Australian species allied to Hakea ulicina R.Br.(Proteaceae). J. Adelaide Bot. Gard. 7: 249271.

LabILlardière, J., 1800: RELATION DU VOYAGE A LA RECHERCHE DE LA PEROUSE. 2 vols. \& atlas. Paris,

LEE, H.M., 1987: The biology of Hakea epiglottis Labill. (Proteaceae), Aust. J. Bot. 35: 689-699.

RICHARDS, A.J., 1986: PLANT BREEDING SYSTEMS. George Allen \& Unwin, London.

Stafleu, F.A. \& Cowan, R.S., 1976-88: TAXONOMIC LITERATURE. A SELECTIVE GUIDE TO BOTANICAL PUBLICATIONS WITH DATES, COMMENTARIES AND TYPES. 2nd edn, Bohn, Scheltema \& Holkema, Utrecht.

StONES, M. \& CuRTIS, W., 1978: THE ENDEMIC FLORA OF TASMANIA. Vol.6. Ariel Press, London.

SutTon, C.S., 1932: Gustav Weindorfer. Vict. Nat. 49: $34-38$.

(accepted 10 August 1990)

R.M. Barker

State Herbarium of South Australia, Botanic Gardens of Adelaide, North Terrace, Adelaide, SA, Australia 5000 